\title{
Modeling, Monitoring and Prediction of Drought in Iran
}

\author{
B. Sobhani ${ }^{1}$, V. Safarian Zengir ${ }^{1 *}$, M.K. Kianian ${ }^{2}$ \\ ${ }^{1}$ Department of physical Geography, Climatology, Faculty of Literature and Humanities, University of Mohaghegh Ardabili, Ardabil, Iran \\ 2 Desert Studies Faculty, Semnan University, Semnan, Iran
}

\section{PAPER INFO}

\section{Paper history:}

Received 05 August 2019

Accepted in revised form 16 September 2019

\section{Keywords:}

Anfis Model

Drought

Fuzzy

Statistical Evaluation

TIBI Index

\section{A $B$ S $S T R$ R A $C$ T}

The drought phenomenon is not specific to the region and it affects different parts of the world. One of these areas is Iran in Southwest Asia, which suffered from this phenomenon in recent years. The purpose of this study is to model, analyze and predict the drought in Iran. To do this, climatic parameters (precipitation, temperature, sunshine, minimum relative humidity and wind speed) were used at 30 stations in the period of 29 years (1990-2018). For modeling of TIBI fuzzy index, first, four indicators (SET, SPI, SEB, MCZI) were fuzzy in Matlab software. Then the indices were compared and Topsis model were used for prioritizing areas involved with drought. Finally, Anfis adaptive artificial neural network model was used to predict. Results showed that the new fuzzy index TIBI for classifying drought reflected four of the above indicators with high accuracy. Among these five climatic parameters used in this study, the temperature and precipitation parameters had the most influential effect on the fluctuation of drought severity. The severity of drought was more based on a 6-month scale modeling than 12 months. The highest percentage of drought occurrence was at Bandar Abbas station with a value of 24.3 on a 12 -month scale and the lowest was in Shahrekord station with a percentage of $0.36 \%$ on a six-month scale. Based on Anfis model and TIBI fuzzy index, Bandar Abbas, Bushehr and Zahedan stations were more exposed to drought due to the TIBI index of $0.62,0.96$ and 0.97 , respectively. According to the results in both 6 and 12 months scale, the southern regions of Iran were more severely affected by drought, which requires suitable water management in these areas.

doi: $10.5829 /$ ijee.2019.10.03.09

\section{INTRODUCTION}

Drought is one of the natural hazards that is dominated by climate change. Drought is also one of the most important natural disasters affecting agriculture and water resources [1]. In recent years, different regions of the world have experienced more severe drought [2]. In addition, drought is a natural phenomenon that occurs in all climatic conditions and in all parts of the planet [3]. Also, drought as a climatic phenomenon greatly affects all aspects of human activity [4]. Other internal and external researchers have investigated various models in the field of drought, including: [5-9]. The investigation conducted by Alizadeh et al. [7], in a research named at the modeling of dispersion of drought caused by climate change in Iran using dynamic system conclude that at all stations, the values of evapotranspiration of the reference plant) increased from January to July, then fell to December, and all stations reached their maximum levels in July. Komasi et al. [10] conducted a drought prediction with SPI and EDI indexes using ANFIS modeling method in Kohgiluyeh and Boyerahmad province. They concluded that clustering increases the accuracy of modeling at the stage of calibration. Byzedi [11] evaluated the drought of synoptic stations in the west of the country using HERBST method and comparative neuro-fuzzy model. They concluded that the coefficient of determination and the error rate of the model were not better than those of Kermanshah, Mianeh and Piranshahr stations. Anumalla et al. [12] estimated droughts using smart grids and showed that the use of wavelet neural network model could be effective in drought estimation. Ekhtiari khajeh and Dinpazhoh [13] applied the Effective Drought Index (EDI) to study drought periods. The results showed that the years of 2005-2007, 2005-2007 and 2002-2003 are the driest year for Tabriz, Bandar Anzali and Zahedan stations respectively during the 60 years statistical period. Zeleki et al. [14] have used the Standard Precipitation Index (SPI) and Palmer Drought Index (PDSI) and satellite data to investigate the drought in Ethiopia. The results showed that the observed dry and wet periods in the north of the study area mainly depend on the change of the ENSO in the spring and summer season, while the drying trend in the south and southwest is associated with the warming of the Atlantic and the surface water temperature in the western Pacific Ocean. Quesada-Montano et al. [15] have studied hydrological changes in a consistent approach to assess flood and 
drought changes and concluded that most of the methods used to detect extreme hydrologic trends are not suitable for trend detection and cannot be used in decision making. Therefore, they proposed a method based on the theory of implementation and threshold level. In order to study the regional climatic models (RCMS), Um et al. [16] examined the observed drought characteristics based on the SPEL in Central Asia, and the results showed that RCMs are correct in humid areas, but in arid areas is incorrect and this model cannot achieve drought events for large spatial scales. Modaresirad et al. [17] studied the drought of meteorological and hydrological in west of Iran. The results showed that the SPI index can show two main characteristics of meteorological and hydrological droughts and also provide accurate estimation for recurrence of a severe drought. Kasi et al. [18], in their research, analyzed the dry and wet conditions using RCM and concluded that uncertainty exists in weather forecasts. However, according to their results, probably dryer summers will occur in the southern regions and more severe precipitation will occur in the winter and autumn in the northern regions of the study area in the future. According to studies conducted inside and outside the country for the present study, many researchers have conducted research on drought monitoring and prediction, but an investigation that can show the drought phenomenon with a more accurate future vision is not done if it does, not adequately address the issue. Accordingly, the researchers conducted this research to model, monitor and predict the drought with the new method in Iran.

\section{MATERIALS AND METHODS}

The present study conducts modeling, monitoring and prediction of drought in Iran using climatic data including precipitation, temperature, sunshine, relative humidity and wind speed (as monthly and yearly and in 6 and 12 months' scale) for the time period The 29-year (1990-2018) for 30 stations by implication of TIBI new index (that calculated by four valid indicators of WMO including SET, SPI, SEB, MCZI). The position of the study area was presented in Figure 1.

For modeling of the new TIBI index, the climatic data were first normalized, then four indices of SET, SPI, SEB, MCZI were calculated separately and the fuzzy modeling of the four indices was performed in the Matlab software and eventually to prioritize the drought-affected areas, Topsis model was used. For the standardization of the SET, SPI indicators, it was used in Equation (1) and SEB MCZI indices, was used from Equation (2).

$$
\begin{aligned}
\mathrm{x}_{\mathrm{ij}} & =\frac{x_{j} \max -x_{j}}{x_{j} \max -x_{j} \min } \\
\mathrm{x}_{\mathrm{ij}} & =\frac{x_{j}-x_{j} \min }{x_{j} \max -x_{j} \min }
\end{aligned}
$$

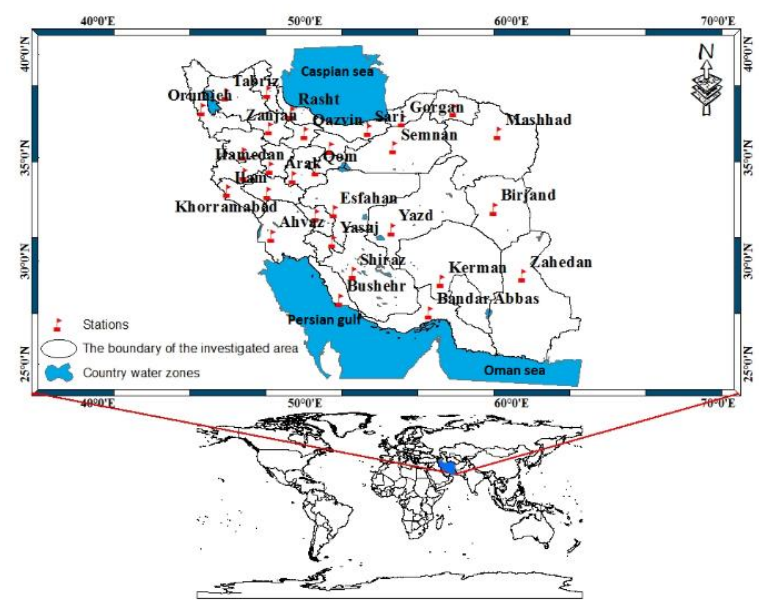

Figure 1. Geographical location of the study area

In these relationships, xij represents the standardized value, $x j$ the desired index value, xjmax the maximum value in the number series, and xjmin represents the lowest value in the numeric series [19]. One of the ways in which linguistic expressions in regular words can be converted to their corresponding fuzzy numbers is to use membership functions in the Matlab software, with the range of four inputs between $2 \pm$ (Table 1 ) and the output index domain is between 0 and 1 (Table 2).

After the modeling of the TIBI fuzzy index, the effect of climate parameters on the drought of the studied stations was investigated. Then drought was monitored. In drought monitoring based on TIBI, trend, the severity of persistence and frequency of drought occurrence were

TABLE 1. Linguistic variables and fuzzy values of input indices (SET, SPI, SEB, MCZI)

\begin{tabular}{lc}
\hline Language variables & Fuzzy value \\
\hline WVH & $2 \geq$ \\
WH & $1.5-1.99$ \\
WA & $0.99-1.39$ \\
WS & $0.5-0.99$ \\
N & $-0.39-0.39$ \\
DS & $-0.99--0.5$ \\
DA & $-1--1.39$ \\
DH & $-1.5--1.99$ \\
DVH & $-2 \leq$ \\
\hline
\end{tabular}

TABLE 2. Linguistic variables and fuzzy values of the new index derived from the modeling of TIBI

\begin{tabular}{lc}
\hline Language variables & Fuzzy value \\
\hline WVH & $0,0,0,0.1$ \\
WH & $0,0.1,0.1,0.2$ \\
WA & $0,0.2,0.2,0.4$ \\
WS & $0.2,0.35,0.35,0.5$ \\
N & $0.3,0.5,0.5,0.7$ \\
DS & $0.5,0.65,0.65,0.8$ \\
DA & $0.6,0.8,0.8,1$ \\
DH & $0.8,0.9,0.9,1$ \\
DVH & $0.9,1,1,1$ \\
\hline
\end{tabular}


studied and the trend of the indices was determined by linear trend method. Frequency relationship was used to obtain the percentage of drought occurrence in different classes.

\section{RESULTS AND DISCUSSION}

Monitoring of drought fluctuations based on four integrated indicators in TIBI

In order to investigate the effect of indices drought fluctuations in drought conditions of stations, it is possible to analyze the changes in the indicators (SET, SPI, SEB, MCZI) as appeared in the TIBI index. Considering the large number of stations, for the sake of better understanding, only the drought series graph of Bojnord station was presented in both 6-and 12-month scale (Figures 2 and 3) (in these figures, the crosssectional red line shows drought margin on a 6-month and more scale with the amount of 0.74 and on a 12 month and more scale with the amount of 0.76
The analysis of these figures shows that at the 6 and 12-month scale at Bojnourd station, the amount of evapotranspiration was similar in drought conditions, which decreased from April 1994 to February 1999, and after this month an increase was observed, while the impact of rainfall on a 6-month scale is weaker than the 12-month scale. It means that from May 1993 to November 1997, an increasing trend occurred and after that followed by the same pattern. The indicators (SET, SPI, SEB, MCZI) affect the TIBI index and show somehow a trend, indicating that the new TIBI fuzzy index reflects the four indicators well. The scale of its drought classes were presented in (Table 3). The TIBI index at the 6-month scale shows a sharper shape than the 12-month scale.

According to the results obtained from the frequency of drought in the 6 and 12-month scale, the total percentages of drought were at 12-months was more than 6-months scale but drought severity at 6-months scale was more than 12 -months scale.

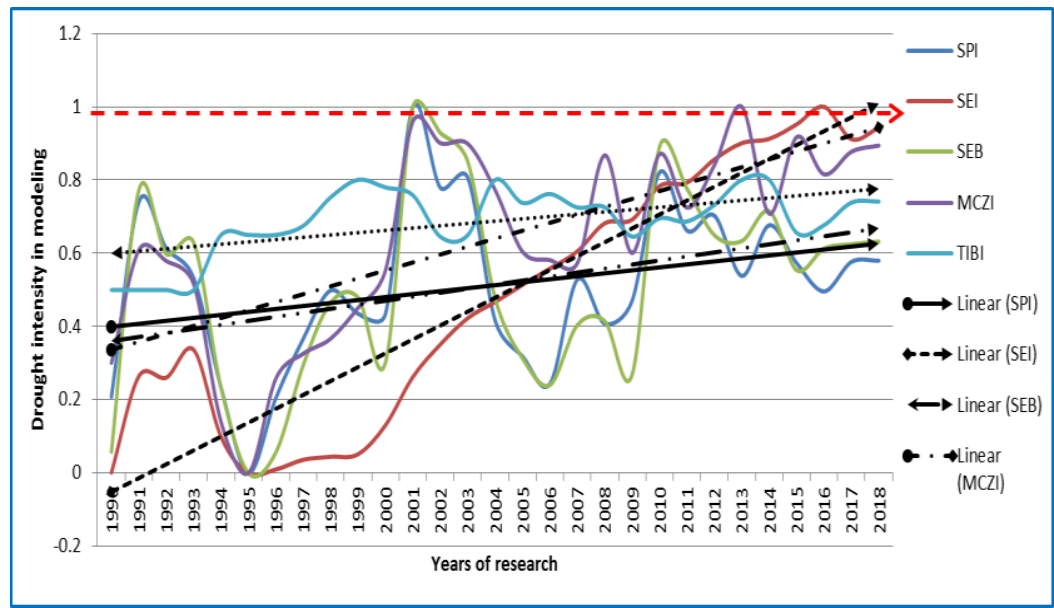

Figure 2. Fluctuation of the indices at the Bojnourd station at the 6-month scale and statistical period of (1990-2018)

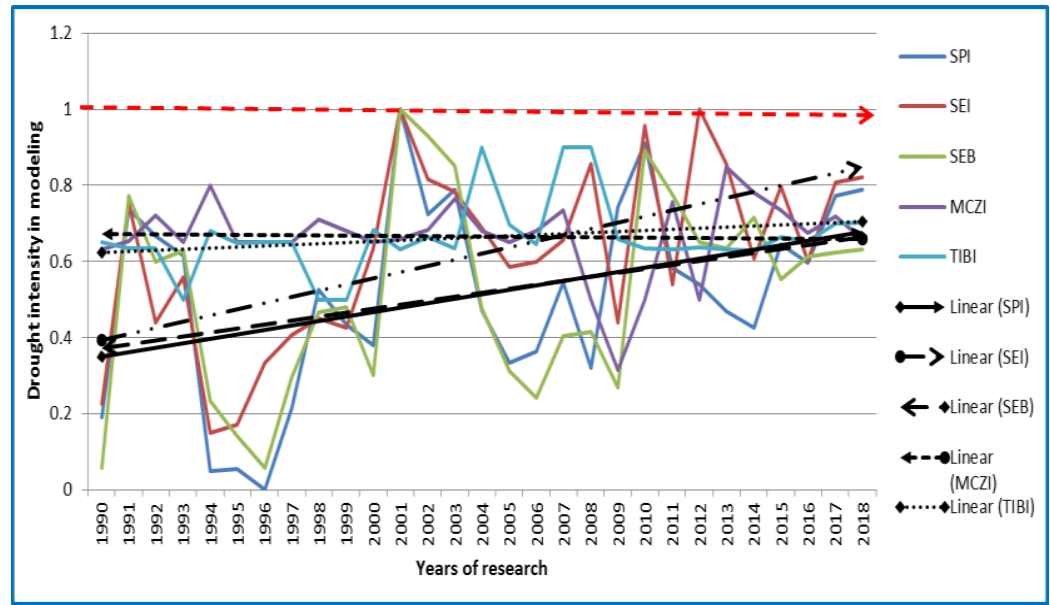

Figure 3. Fluctuation of the indices at the Bojnourd station at the 12-month scale and statistical period of 1990-2018 
In the study area at 6- months scale, the severity of drought was more pronounced in the south, west and center of Iran. The stations of Bandar Abbas, Bushehr in the south and Ahwaz in the southwest and Zahedan in the south-east of the study area had most percentages of drought (16.62, 11.24, 14.13 and 6.62, respectively). Stations with a lower percentage of drought severity were more frequently in north-west, north and west parts of the region including the stations of Urmia and Ardebil in northwest of Iran with frequency percentage of 1.10 and 1.88, Ilam and Yasuj with percentage of 1.61 and 2.01) in west of Iran, Rasht and Gorgan, with percentage of 1.26 and 0.87 in the north of the study area (Table 4, Figure 4).
TABLE 3. Drought severity classification based on fuzzy modeling of TIBI

\begin{tabular}{lc}
\hline Drought classes & Index value of T.I.B.I \\
\hline Very severe drought & $0.96-1$ \\
severe drought & $0.87-0.96$ \\
moderate drought & $0.74-0.87$ \\
mild drought & $0.59-0.74$ \\
Normal drought & $0.44-0.59$ \\
Mild wet season & $0.29-0.44$ \\
Moderate wet season & $0.15-0.29$ \\
Severe wet season & $0.06-0.15$ \\
Very severe wet season & $0 .-0.06$ \\
\hline
\end{tabular}

TABLE 4. The frequency percent of drought incidence in different classes in the 6-month time scale and statistical period of (19902018)

\begin{tabular}{|c|c|c|c|c|c|c|c|c|c|c|c|c|}
\hline No. & $\begin{array}{l}\text { Station } \\
\text { names }\end{array}$ & $\begin{array}{c}\text { Very } \\
\text { severe wet } \\
\text { season }\end{array}$ & $\begin{array}{l}\text { Severe } \\
\text { wet } \\
\text { season }\end{array}$ & $\begin{array}{c}\text { Moderate } \\
\text { wet season }\end{array}$ & $\begin{array}{c}\text { Mild } \\
\text { wet } \\
\text { season }\end{array}$ & Normal & $\begin{array}{c}\text { Mild } \\
\text { drought }\end{array}$ & $\begin{array}{l}\text { Moderate } \\
\text { drought }\end{array}$ & $\begin{array}{c}\text { Severe } \\
\text { drought }\end{array}$ & $\begin{array}{c}\text { Very } \\
\text { severe } \\
\text { drought }\end{array}$ & $\begin{array}{c}\text { Very } \\
\text { severe wet } \\
\text { season }\end{array}$ & Total \\
\hline 1 & Ormia & 0 & 0.5 & 0.19 & 0.14 & 0.03 & 1.19 & 0.15 & 0.82 & 0.13 & 0 & 1.10 \\
\hline 0 & Tabriz & 0.01 & 0 & 0.23 & 0.19 & 1.41 & 0.47 & 1.04 & 1.09 & 0.07 & 0.01 & 2.20 \\
\hline 3 & Ardebil & 0.03 & 0 & 0.39 & 0.39 & 3.25 & 0.36 & 1.21 & 0.58 & 0.09 & 0.03 & 1.88 \\
\hline 4 & Esfahan & 0 & 0.09 & 0.01 & 0.01 & 0.56 & 1.25 & 0.26 & 0.19 & 0.47 & 0 & 0.92 \\
\hline 5 & Ilam & 0 & 0 & 0 & 0.05 & 1.64 & 0.08 & 1.5 & 0.11 & 0 & 0 & 1.61 \\
\hline 6 & Boushehr & 0 & 0 & 0 & 0.01 & 3.99 & 7.89 & 4.54 & 6.11 & 0.59 & 0 & 11.24 \\
\hline 7 & Tehran & 0 & 0.06 & 0 & 0.61 & 1.74 & 2.41 & 1.3 & 2.23 & 0.02 & 0 & 3.55 \\
\hline 8 & Shahrekord & 0 & 0 & 0.08 & 0.32 & 1.21 & 1.54 & 0.23 & 0.11 & 0.02 & 0 & 0.36 \\
\hline 9 & Birjand & 0 & 0 & 0 & 0 & 2.34 & 3.87 & 0.45 & 0.02 & 0 & 0 & 0.47 \\
\hline 10 & Mashhad & 0 & 0 & 0.14 & 0.11 & 1.4 & 4.41 & 1 & 1.57 & 0.11 & 0 & 2.68 \\
\hline 11 & Bojnord & 0 & 0 & 0.04 & 0 & 1.5 & 1.15 & 3.09 & 2.12 & 0.04 & 0 & 5.25 \\
\hline 12 & Ahvaz & 0 & 0 & 0 & 0.09 & 4.54 & 9.12 & 6.47 & 7.15 & 0.51 & 0 & 14.13 \\
\hline 13 & Zanjan & 0 & 0 & 0.12 & 0.41 & 1.18 & 4.12 & 2.74 & 3.3 & 0 & 0 & 6.04 \\
\hline 14 & Semnan & 0 & 0 & 0.01 & 0.01 & 2.14 & 5.18 & 3.13 & 0.95 & 0 & 0 & 4.08 \\
\hline 15 & Zahedan & 0 & 0 & 0 & 0.09 & 1.44 & 3.19 & 1.48 & 5.10 & 0.04 & 0 & 6.62 \\
\hline 16 & Shiraz & 0 & 0 & 0.05 & 1.14 & 1.10 & 4.71 & 1.09 & 0.64 & 0.14 & 0 & 1.87 \\
\hline 17 & Ghazvin & 0 & 0 & 0.03 & 0.11 & 2 & 2.23 & 2.11 & 1.45 & 0 & 0 & 3.56 \\
\hline 18 & Ghom & 0 & 0 & 0.09 & 0.16 & 1.45 & 1.17 & 1.23 & 4.87 & 0 & 0 & 6.10 \\
\hline 19 & Sanandaj & 0 & 0 & 0 & 0.29 & 2.36 & 2.09 & 1.85 & 3.58 & 0.05 & 0 & 5.48 \\
\hline 20 & Kerman & 0 & 0 & 0 & 0.15 & 1.31 & 3.07 & 3.87 & 1.89 & 0.03 & 0 & 5.79 \\
\hline 21 & Kermanshah & 0 & 0 & 0.01 & 0.18 & 0.64 & 4.48 & 1.25 & 2.85 & 0 & 0 & 4.10 \\
\hline 22 & Yasouj & 0 & 0 & 0.04 & 0.25 & 1.41 & 1 & 1.65 & 0.26 & 0.10 & 0 & 2.01 \\
\hline 23 & Gorgan & 0 & 0 & 0.28 & 0.36 & 1.41 & 1.43 & 0.12 & 0.75 & 0 & 0 & 0.87 \\
\hline 24 & Rasht & 0 & 0 & 0.69 & 0.48 & 0.74 & 3.74 & 0.12 & 1.14 & 0 & 0 & 1.26 \\
\hline 25 & Khorramabad & 0 & 0.09 & 0 & 0 & 0.54 & 2.28 & 1.31 & 0.12 & 0.09 & 0 & 1.52 \\
\hline 26 & Sari & 0 & 0 & 0.03 & 0.06 & 0.14 & 2.74 & 1.08 & 0.45 & 0.18 & 0 & 1.71 \\
\hline 27 & Arak & 0 & 0 & 0.01 & 0.07 & 1.47 & 1.68 & 2.74 & 2.18 & 0.23 & 0 & 5.15 \\
\hline 28 & Bandarabbas & 0 & 0 & 0 & 0.21 & 5.18 & 12.58 & 8.07 & 8.19 & 0.36 & 0 & 16.62 \\
\hline 29 & Hamedan & 0 & 0 & 0.09 & 0.09 & 0.32 & 1.10 & 3.85 & 0.08 & 0 & 0 & 3.93 \\
\hline 30 & Yazd & 0 & 0 & 0 & 0 & 0.87 & 3.86 & 1.35 & 0.79 & 0.02 & 0 & 2.16 \\
\hline
\end{tabular}




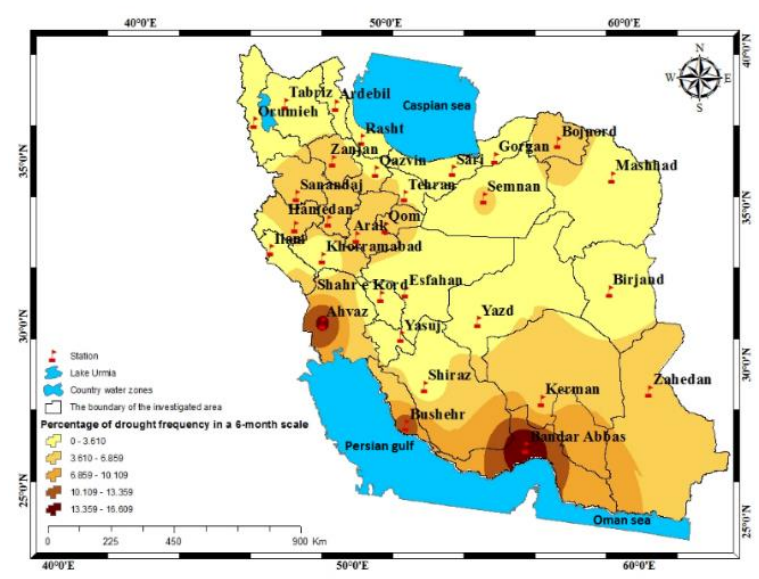

Figure 4. The zoning of the frequency percent of drought occurrence in the studied stations in a 6-month scale and statistical period of (1990-2018)
According to the model, in the 12-month scale, semisouthern regions of Iran were more exposed to drought. The stations of Bandar Abbas and Bushehr in the south of the study area with drought frequency percent of 24.3 and 14.83, Ahvaz with 18.47 in the southwest of the study area, Kerman with the amount 6.74 in southeastern of Iran had the highest percentage of drought occurrence in the 12-month scale, but stations of Birjand (1.7) and Bojnurd (3.66) in the northeast, Urmia (1.17) and Tabriz (2.66) in northwestern of Iran, Rasht (0.58) and Sari (0.78) in north of Iran had the lowest percentage of drought frequency at the 12-month scale (Table 5, Figure 5).

Depending on the definition of drought based on the TIBI index, values of 0.74 and higher, or from a mild drought class to higher, are raised as dry conditions.

TABLE 5. The frequency percent of drought incidence in different classes in the 12-month scale and statistical period of (1990-2018)

\begin{tabular}{|c|c|c|c|c|c|c|c|c|c|c|c|}
\hline No. & $\begin{array}{l}\text { Station } \\
\text { names }\end{array}$ & $\begin{array}{c}\text { Severe } \\
\text { wet } \\
\text { season }\end{array}$ & $\begin{array}{c}\text { Moderate } \\
\text { wet season }\end{array}$ & $\begin{array}{c}\text { Mild } \\
\text { wet } \\
\text { season }\end{array}$ & Normal & $\begin{array}{c}\text { Mild } \\
\text { drought }\end{array}$ & $\begin{array}{c}\text { Moderate } \\
\text { drought }\end{array}$ & $\begin{array}{c}\text { Severe } \\
\text { drought }\end{array}$ & $\begin{array}{c}\text { Very } \\
\text { severe } \\
\text { drought }\end{array}$ & $\begin{array}{c}\text { Very } \\
\text { severe wet } \\
\text { season } \\
\end{array}$ & Total \\
\hline 1 & Ormia & 0 & 0.32 & 0.09 & 0.11 & 0.69 & 1.12 & 0.12 & 0.91 & 0.14 & 1.17 \\
\hline 0 & Tabriz & 0 & 0 & 0.26 & 0.12 & 1.96 & 3.59 & 2.16 & 0.41 & 0.09 & 2.66 \\
\hline 3 & Ardebil & 0.01 & 0.03 & 0.42 & 0.40 & 2.37 & 0.76 & 2.28 & 0.49 & 0.011 & 2.781 \\
\hline 4 & Esfahan & 0 & 0 & 0.04 & 0.13 & 1.89 & 1.59 & 0.48 & 0.99 & 0.39 & 1.86 \\
\hline 5 & Ilam & 0 & 0.02 & 0.06 & 0.09 & 2.99 & 2.98 & 2.69 & 0.39 & 0.10 & 3.18 \\
\hline 6 & Boushehr & 0 & 0 & 0 & 0 & 8.38 & 8.02 & 5.69 & 7.79 & 1.35 & 14.83 \\
\hline 7 & Tehran & 0 & 0 & 0 & 0.17 & 3.84 & 3.12 & 2.78 & 1.63 & 0.16 & 4.57 \\
\hline 8 & Shahrekord & 0 & 0 & 0.02 & 0.14 & 2.84 & 1.78 & 0.47 & 0.98 & 0.18 & 1.63 \\
\hline 9 & Birjand & 0 & 0 & 0 & 0.09 & 2.89 & 1.81 & 0.87 & 0.79 & 0.04 & 1.70 \\
\hline 10 & Mashhad & 0 & 0 & 0 & 0.08 & 4.49 & 3.51 & 2.01 & 2.61 & 0.13 & 4.75 \\
\hline 11 & Bojnord & 0 & 0 & 0.02 & 0.07 & 2.69 & 2.39 & 2.14 & 1.49 & 0.03 & 3.66 \\
\hline 12 & Ahvaz & 0 & 0 & 0 & 0 & 10.96 & 10.66 & 7.14 & 9.89 & 1.44 & 18.47 \\
\hline 13 & Zanjan & 0 & 0 & 0.04 & 0.06 & 5.98 & 5.41 & 3.89 & 2.76 & 0 & 6.65 \\
\hline 14 & Semnan & 0 & 0 & 0.02 & 0.04 & 3.47 & 4.13 & 2.93 & 0.84 & 0.01 & 3.78 \\
\hline 15 & Zahedan & 0 & 0 & 0 & 0 & 3.81 & 2.79 & 2.56 & 3.08 & 0.24 & 5.88 \\
\hline 16 & Shiraz & 0 & 0 & 0.03 & 0.07 & 2.58 & 2.49 & 1.74 & 0.44 & 0.29 & 2.47 \\
\hline 17 & Ghazvin & 0 & 0 & 0.02 & 0.01 & 1.78 & 4.69 & 3.36 & 2.38 & 0.13 & 5.87 \\
\hline 18 & Ghom & 0 & 0 & 0.07 & 0.12 & 3.84 & 2.96 & 2.76 & 3.79 & 0.01 & 6.56 \\
\hline 19 & Sanandaj & 0 & 0 & 0 & 0.19 & 4.87 & 3.85 & 3.69 & 2.45 & 0.09 & 6.23 \\
\hline 20 & Kerman & 0 & 0 & 0 & 0 & 2.98 & 2.51 & 1.69 & 4.63 & 0.69 & 6.74 \\
\hline 21 & Kermanshah & 0 & 0 & 0.08 & 0.13 & 1.87 & 4.04 & 3.13 & 1.71 & 0.04 & 4.88 \\
\hline 22 & Yasouj & 0 & 0 & 0.09 & 0.14 & 2.96 & 3.36 & 2.28 & 2.37 & 0.15 & 4.80 \\
\hline 23 & Gorgan & 0 & 0 & 0.18 & 0.24 & 2.57 & 1.36 & 0.29 & 0.81 & 0 & 1.10 \\
\hline 24 & Rasht & 0 & 0.24 & 0.51 & 0.63 & 1.68 & 1.71 & 0.49 & 0.09 & 0 & 0.58 \\
\hline 25 & Khorramabad & 0 & 0 & 0 & 0.11 & 1.41 & 3.36 & 2.56 & 0.99 & 1.94 & 5.49 \\
\hline 26 & Sari & 0 & 0.08 & 0.28 & 0.67 & 3.89 & 1.14 & 0.07 & 0.14 & 0.85 & 0.79 \\
\hline 27 & Arak & 0 & 0 & 0.29 & 0.41 & 3.52 & 2.14 & 1.98 & 1.11 & 0.17 & 3.26 \\
\hline 28 & Bandarabbas & 0 & 0 & 0 & 0 & 14.46 & 13.19 & 10.42 & 11.89 & 1.99 & 24.30 \\
\hline 29 & Hamedan & 0 & 0.02 & 0.13 & 0.18 & 0.76 & 2.81 & 2.74 & 0.09 & 0 & 2.83 \\
\hline 30 & Yazd & 0 & 0 & 0 & 0 & 0.98 & 2.91 & 2.51 & 0.47 & 0.08 & 3.06 \\
\hline
\end{tabular}




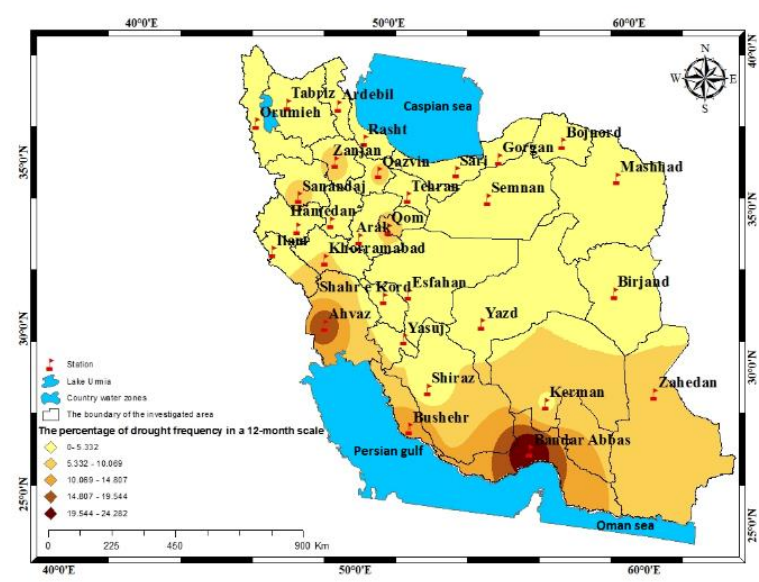

Figure 5. The zoning of the frequency percent of drought occurrence in the studied stations in a 12-month scale and statistical period of (1990-2018)

Accordingly, in modeling of the TIBI fuzzy index, the severity of drought in the 6-month scale was more than the 12-month scale. Based on the results, the annual drought severity at 6-month and 12-month scale began since 1994 and 1996 respectively and it has continued ascending.

\section{Assessment of drought-affected areas based on the TOPSIS model}

Prioritization of the stations involved in drought in Iran was analyzed using TOPSIS model. To calculate and analyze the statistical data, each of the parameters took a weight and then the desirability and the lack of desirability of each of the studied stations was investigated in terms of climatic indices and, finally, an appropriate option was selected from an approximate approach to ideal proportions. The results of the implementation of the TOPSIS model using the degree of importance of the criteria derived from the entropy method indicate that, in terms of drought, more and less places are involved with drought by combining the two 6 and 12-month scale were identified according to the TOPSIS model. The three stations of Bandar Abbas, Ahvaz and Bushehr in the south and southwest of Iran with priority values of $1,0.78$, and 0.62 were most affected respectively by the drought, based on the TOPSIS model and three stations of Gorgan, Shahr-eKord and Urmia in the north and west regions of Iran were rated as $0.026,0.033,0.03$ and 0.035 , respectively had less priority for drought occurrence (Figure 6, Table $6)$.

\section{Drought prediction based on ANFIS model}

After modeling of drought indices and reassurance, TIBI index was predicted for the next 16 years using the Anfis adaptive neural network model. After verifying the validity of neural network models in modeling, Anfis Neural Network model showed more precision for predicting drought phenomena. Drought index data of TIBI was estimated for the time period of 2019-2033.

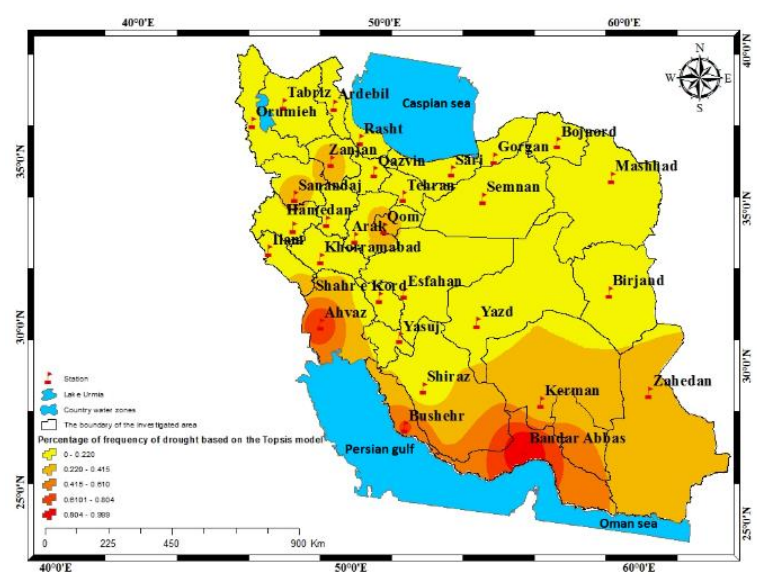

Figure 6. Final map of areas affected by drought in Iran based on the Topsis model during the statistical period of (1990-2018)

TABLE 6. Prioritization of drought-infected stations based on the Topsis model during statistical period of (1990-2018)

\begin{tabular}{|c|c|c|c|c|c|c|c|c|}
\hline $\begin{array}{c}\text { Station } \\
\text { names }\end{array}$ & $\begin{array}{l}\text { Topsis } \\
\text { value }\end{array}$ & $\begin{array}{c}\text { Topsis rating } \\
\text { score }\end{array}$ & $\begin{array}{c}\text { Station } \\
\text { names }\end{array}$ & $\begin{array}{c}\text { Topsis } \\
\text { value }\end{array}$ & $\begin{array}{c}\text { Topsis rating } \\
\text { score }\end{array}$ & $\begin{array}{c}\text { Station } \\
\text { names }\end{array}$ & $\begin{array}{l}\text { Topsis } \\
\text { value }\end{array}$ & $\begin{array}{c}\text { Topsis rating } \\
\text { score }\end{array}$ \\
\hline Kermanshah & 0.203 & 12 & Bojnord & 0.2147 & 9 & Ormia & 0.0351 & 28 \\
\hline Yasouj & 0.1495 & 18 & Ahvaz & 0.7898 & 2 & Tabriz & 0.0992 & 20 \\
\hline Gorgan & 0.0263 & 30 & Zanjan & 0.2976 & 5 & Ardebil & 0.0931 & 22 \\
\hline Rasht & 0.0356 & 27 & Semnan & 0.1795 & 14 & Esfahan & 0.0466 & 25 \\
\hline Khorramabad & 0.1611 & 16 & Zahedan & 0.2982 & 4 & Ilam & 0.0969 & 21 \\
\hline Sari & 0.0537 & 24 & Shiraz & 0.0855 & 23 & Boushehr & 0.6291 & 3 \\
\hline Arak & 0.205 & 11 & Ghazvin & 0.2122 & 10 & Tehran & 0.1805 & 13 \\
\hline Bandarabbas & 1 & 1 & Ghom & 0.2973 & 6 & Shahrekord & 0.0333 & 29 \\
\hline Hamedan & 0.1578 & 17 & Sanandaj & 0.2724 & 7 & Birjand & 0.0359 & 26 \\
\hline Yazd & 0.1072 & 19 & Kerman & 0.2509 & 8 & Mashhad & 0.1624 & 15 \\
\hline
\end{tabular}


Based on the results of predictions, stations of Bandar Abbas, Bushehr and Zahedan, with the TIBI index of $0.62,0.96$ and 0.97 in southern of Iran, were more exposed to drought for the coming years but the stations of Urmia, Tabriz and Shahr-e-Kord, respectively had the lowest amount of drought based on the TIBI index with the amount of $0.17,0.15$ and 0.12), respectively (Figures 7 and 8).

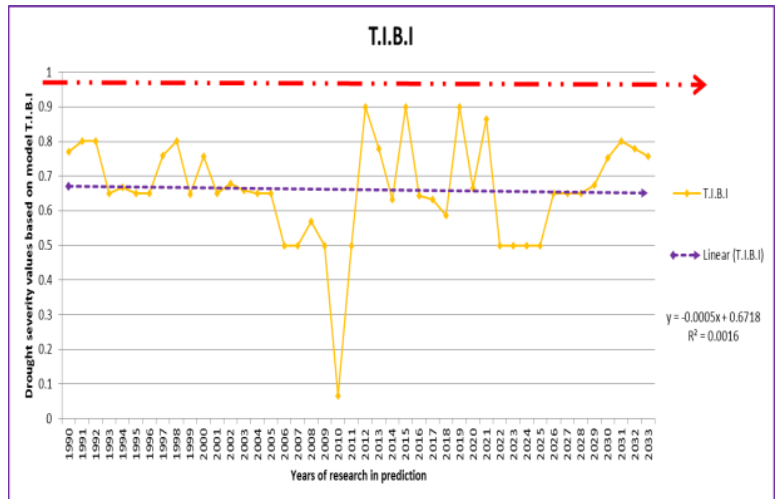

Figure 7. Drought simulation diagram based on T.I.B.I model at Bojnourd station during statistical period of (20192033)

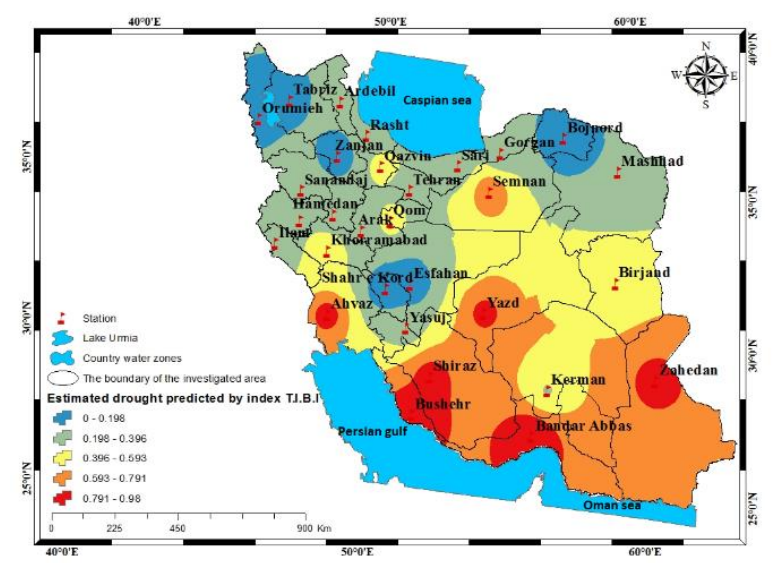

Figure 8. Drought mapping in simulated years based on T.I.B.I model during statistical period of (2019-2033)

\section{CONCLUSION}

Drought is a natural disaster that is gradually evolving under the influence of climatic abnormalities over a long period of time. In recent years, various parts of the Middle East have faced drought, including Iran in Southwest Asia. In this study, the drought phenomenon was predicted in two 6-months and 12-months scales using TIBI's new fuzzy index. The results of the study showed that the total frequency of drought was more at 12- months than those of at 6-months, but the severity of 6-months drought is more than those of at 12 months. On a 12-months scale, drought repetitions and its continuity is more than 6 months. Drought was less continuous in short-run time scale and affected by temperature parameter, while the severity of drought in the long periods of time was less responsive to rainfall variations. The highest percentage of drought incidence in 6-months scale was for Bandar Abbas, Bushehr, Ahvaz and Zahedan stations in the southern section of the study area with the frequency of drought of 16.62, 11.24, 14.13 and 6.62 respectively and the lowest at 6-month scale was for Urmia, Ardebil, Ilam and Yasuj stations with frequency percent of 1.10, 1.88, 1.61 and 2.01 respectively. Also, Rasht and Gorgan had the drought severity of 1.26 and 0.87 in the north and west of Iran. The highest frequency of drought incidence in 12-months scale was for Bandar Abbas and Bushehr stations respectively with drought frequency percentage of 24.30 and 14.83, Ahvaz with drought severity of 18.47 and Kerman with drought frequency of 6.74 in the south and southwest of Iran and the lowest at the 6-month scale were stations of Birjand (1.70), Bojnurd (3.66), Urmia (1.17) and Tabriz (2.66) in the northwest of Iran, Rasht (0.58) and Sari (0.78) in the northern part of Iran. Also, based on Topsis model, Bandar Abbas, Ahwaz and Bushehr stations in south and southwestern Iran were prioritized with high drought severity $(1,0.78$, and 0.62 respectively). The prediction of drought based on the Anfis comparative neural network model indicates that Bandar Abbas, Bushehr and Zahedan stations with the TIBI index of $0.62,0.96$ and 0.97 respectively in southern regions of Iran were mostly exposed to drought for the coming years.,

In this research, we studied modeling, monitoring and prediction of drought phenomenon in Iran. this method has been used in a few studies and it has been considered as a suitable method for monitoring, analysis and comparison, for example Alizadeh et al. [7] in their research on the modeling of dispersion of droughts due to climate change in Iran by using a dynamical system; Zeinali and Safarian-Zengir [4] in study on drought monitoring in the Lake Urmia Basin using fuzzy index that it had an acceptable performance. Fathi-Zadeh et al. [20] in a research on relationship between meteorological drought and solar variables in some of Iran's interconnection stations, and finally, ParsaMehr and Khosravani [21] in a research, they used Topsis model and verified the efficiency of the models. Also, models in the present study were useful in modeling, monitoring and predicting the drought phenomenon in Iran.

\section{FUNDING}

The author declares that there is no conflict of interests regarding the publication of this manuscript. 


\section{AUTHORS' CONTRIBUTIONS}

B.S, did the calculations, V.SZ, analyzed the results and wrote the paper and M.K, Data collection and analysis.

\section{ACKNOWLEDGEMENTS}

The authors would like to thank the I.R. of Iran Meteorological Organization (IRIMO) for providing the meteorological data for this study. We also would like to thank Dr. Bromand Salahi for writing support. We also acknowledge the support from Mohaghegh Ardabili University.

\section{REFERENCES}

1. Shamsniya, S.A., Pirmoradian, N. and Amiri, S.N. (2009) Drought Modeling in Fars Province Using Time Series Analysis, Journal of Geography and Planning, 14(28), pp. 165-189. [In Persian]

2. Mirzaie Nodoushan, F., Araghinejad, S., Bozorghaddad, O. (2015). Development of WEAP Integrated Water Model Model for Drought Condition Modeling, Watershed Engineering and Management, 7(1), pp.85-97. [In Persian]

3. Samidianfard, S. and Asadi, E., (2018). Prediction of spi drought index using support vector and multiple linear regressions. Journal of Soil and Water Resources Conservation, 6(4), pp.1-16. [In Persian]

4. Zeinali, B. and Safarian Zengir, V., (2017), Drought Monitoring in Urmia Lake Basin Using Fuzzy Index, Journal of Natural Environment Hazards, 6(12), pp.37-61. [In Persian]

5. Haddadi, H. and Heidari, H. (2015). Detection of the effect of precipitation fluctuations on surface water flood in Lake Urmia catchment basin, Geography and Environmental Planning, 57(1), pp.247-262. [In Persian]

6. Sobhani, B., GhafariGilandeh, A and Golvost, A. (2015). Drought monitoring in Ardabil province by means of SEPI fuzzy index developed based on the fuzzy logic, Journal of Geographical Sciences, 15(36), pp.51-72. [In Persian]

7. Alizadeh, S., Mohammadi, H. and Kardavani, P., 2017. Dispersion modeling drought caused by climate change in Iran using system dynamics. Town and Country Planning, 9(1), pp.169-188 [In Persian]
8. Huang, S., Huang, Q., Chang, J., Zhu, Y., Leng, G. and Xing, L., 2015. Drought structure based on a nonparametric multivariate standardized drought index across the Yellow River basin, China. Journal of Hydrology, 530, pp.127-136.

9. Spinoni, J., Naumann, G., Vogt, J.V. and Barbosa, P., 2015. The biggest drought events in Europe from 1950 to 2012. Journal of Hydrology: Regional Studies, 3, pp.509-524.

10. Komasi, M., Alami, M.T. and Nourani, V., 2013. Drought Forecasting by SPI Index and ANFIS Model Using Fuzzy C-mean Clustering. Water and Wastewater, 24(4), pp.90-102.

11. Byzedi, M., 2018. Evaluation of drought in western synoptic stations using herbst and neuro-fuzzy method. Iran-Water Resources Research, 14(1), pp.278-284.

12. Anumalla, S., Ramamurthy, B., Gosselin, D.C. and Burbach, M., 2005, May. Ground water monitoring using smart sensors. In IEEE International Conference on Electro Information Technology, IEEE, pp.1-6.

13. Ekhtiari, S. and Dinpashoh, Y., 2019. Application of effective drought index (EDI) in characterizing drought periods (case study: Tabriz, Bandar-e Anzali and Zahedan stations). Sustainable Water Resources Management, pp.1-7.

14. Zeleke, T.T., Giorgi, F., Diro, G.T. and Zaitchik, B.F., 2017. Trend and periodicity of drought over Ethiopia. International Journal of Climatology, 37(13), pp.4733-4748.

15. Quesada-Montano, B., Di Baldassarre, G., Rangecroft, S. and Van Loon, A.F., 2018. Hydrological change: Towards a consistent approach to assess changes on both floods and droughts. Advances in Water Resources, 111, pp.31-35.

16. Um, M.J., Kim, Y. and Kim, J., 2017. Evaluating historical drought characteristics simulated in CORDEX East Asia against observations. International Journal of Climatology,37(13), pp.4643-4655

17. Modaresirad, A., Ghahraman, B., Khalili, D., Ghahremani, Z. and Ahmadi, S., 2017. Integrated meteorological and hydrological drought model: a management tool for proactive water resources planning of semi-arid regions. Advances in Water Resources, 107, pp.336-353.

18. Kis, A., Pongrácz, R. and Bartholy, J., 2017. Multi-model analysis of regional dry and wet conditions for the Carpathian Region. International Journal of Climatology, 37(13), pp.45434560.

19. Lawal, D.U., Matori, A.N. and Balogun, A.L., 2011. A geographic information system and multi-criteria decision analysis in proposing new recreational park sites in universiti teknologi malaysia. Modern Applied Science, 5(3), pp.39-55.

20. Fathi-Zadeh, H., Gholami-nia, A., Mobin, M. and Soodyzizadeh, H. (2017). Investigating the Relationship between Meteorological Drought and Solar Variables in Some Iranian Standards. Journal of Natural Environment Hazards, 17(6): 63-87. [In Persian]

21. ParsaMehr, A. H. and Khosravani, Z. (2017). Determination of drought determination using multi-criteria decision making based on TOPSIS. Iranian Journal of Range and Desert Research, 24(1), pp. 16-29. [In Persian] 


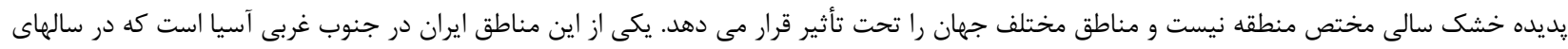

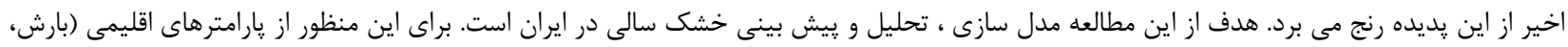

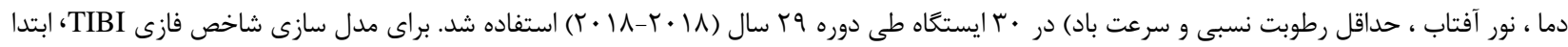

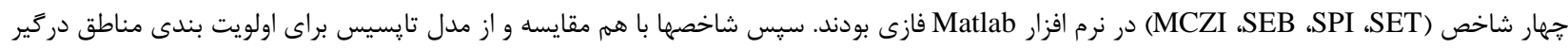

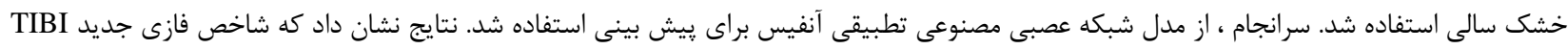

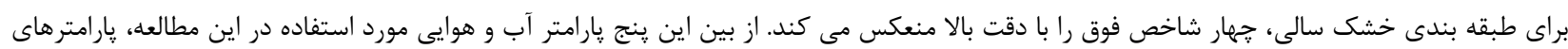

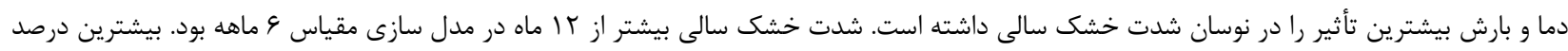

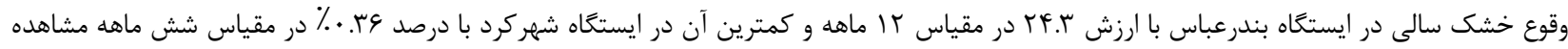

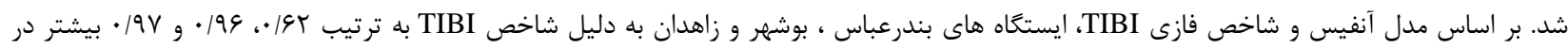

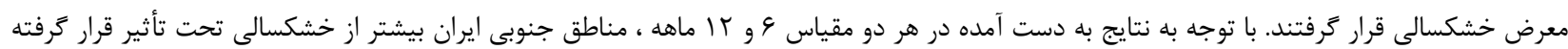

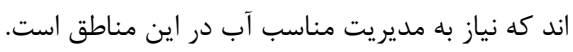

